\title{
Kreativitas Desain Kuliner dan Sistem Inovasi Lokal
}

\author{
Yasraf Amir Piliang, Ruly Darmawan \\ Institut Teknologi Bandung (ITB) \\ Jl. Ganesha No. 10 Bandung
}

\begin{abstract}
The development of creativity in a particular social group, class or community is higly determined by certain capitals invested in the field of creativity: economic, cultural, symbolic and social. This research is an attempt to understand creativity as a part of particular socio-cultural setting, namely a 'field of creativity'. By employing an ethnographic method, this research is an attempt to analyse the relationship between creative ideas and socio-cultural context in which the ideas are produced. Through an intensive field research in local creative communities, this research concludes that creative ideas are higly determined by the comprehensiveness of creative fields: expression, production, dissemination and aprreciation. From these creative fields, three models of system of innovation can be proposed: an open system, liminal system and closed system.
\end{abstract}

Keywords: creative idea, field, innovation, capital

\begin{abstract}
ABSTRAK
Pengembangan kreativitas pada sebuah kelompok, kelas sosial atau komunitas sangat ditentukan oleh modal yang diinvestasikan dalam ranah kreativitas: ekonomi, budaya, simbolik dan sosial. Penelitian ini adalah upaya untuk memahami kreativitas sebagai bagian dari ranah khusus sosial-budaya, yaitu 'ranah kreativitas'. Dengan menggunakan metode etnografi, penelitian ini adalah upaya untuk menganalisis relasi antara ide-ide kreatif dan konteks sosial-budaya di mana ide-ide itu diproduksi. Melalui penelitian lapangan yang intensif terhadap komunitas kreatif lokal, penelitian ini menyimpulkan, bahwa produksi ide-ide kreatif sangat ditentukan oleh kelengkapan sub-sub ranah yang membangun ranah kreatif: ekspresi, produksi, diseminasi dan apresiasi. Berdasarkan ranah-ranah kreatif ini, tiga model sistem inovasi dapat diajukan: sistem terbuka, sistem liminal dan sistem tertutup.
\end{abstract}

Kata kunci: ide kreatif, ranah, inovasi, modal

\section{PENDAHULUAN}

Salah satu masalah sentral dalam pengembangan kreativitas di Indonesia adalah kebergantungan yang sangat besar pada kekuatan-kekuatan eksternal, baik dalam konteks kekuatan sains dan teknologi, kekuatan modal dan regulasi tata kelola ekonomi dan industri. Lembaga-lembaga pemerintah sebagai penyangga dan mesin pendorong pengembangan kreativitas nasional, tampak tak mampu menunjukkan hasil (outcome) yang maksimal, sebagai cara strategis untuk meningkatkan daya saing nasional melalui kreativitas. Potensi-potensi komunitas, kelompok atau kelas-ke- 
las sosial yang ada di Indonesia tak mampu dikelola dengan baik, agar mampu menghasilkan ide dan produk-produk kreatif sebagai sebuah cara kerja sistem.

Di pihak lain, perkembangan industri kreatif di Indonesia yang pada kenyataannya merupakan industri berbasis masyarakat dan tumbuh dari bawah (grass root), menunjukkan pertumbuhan yang sangat signifikan, baik dalam intensitas kegiatan maupun nilai ekonominya. Akan tetapi, pertumbuhan kreativitas ini harus dilihat secara kritis dan komprehensif, khususnya dalam melihatnya sebagai bagian dari sebuah sistem sosial yang terintegrasi dengan cara kerja pemerintah. Dengan memandang kreativitas sebagai bagian dari sistem sosial, dapat diidentifikasi sub-sub sistem kreativitas mana yang bekerja maksimal atau minimal dalam konteks pertumbuhan ide-ide kreatif dalam dalam konteks nasional.

Bila kita melihat kreativitas sebagai sebuah 'ranah' (field), maka apa yang disebut sebagai 'ranah kreativitas' (field of creativity) tidak dapat dilepaskan dari ranah-ranah lainnya yang mendukung: ekonomi, industri, sosial dan budaya. Artinya, kreativitas harus dipandang sebagai sebuah kesatuan sistem terintegrasi dan melingkupi, yang terdiri dari sehimpunan aktor, kelembagaan, jaringan, kemitraan, hubungan interaksi dan proses produktif yang mempengaruhi arah perkembangan dan kecepatan inovasi serta difusi ide-ide kreatif di dalam masyarakat serta realisasinya dalam ranah produksi.

Peningkatan daya saing dalam berbagai tataran serta kohesi sosial dalam proses pembangunan diyakini sebagai penentu keberhasilan dalam meningkatkan kesejahteraan rakyat secara berkelanjutan. Telaah konsep maupun beberapa bukti empiris pengalaman praktik dari mereka yang berhasil dapat menunjukkan bahwa daya saing dan kohesi sosial suatu negara, dae- rah atau masyarakat sangat dipengaruhi oleh perkembangan kreativitas dan ide-ide kreatif di dalamnya.

Kreativitas sebagai motor pendorong perubahan, dengan demikian, menjadi kata kunci yang tak dapat diabaikan dalam pembangunan nasional. Terkait agenda pengembangan industri kreatif di Indonesia, maka peranan kebijakan inovasi, sebagai himpunan dari beragam kebijakan yang saling berkaitan untuk mempengaruhi perkembangan atau penguatan daya kreativitas, baik pada tataran nasional, daerah atau industrial serta sektoral, mempunyai peranan sentral dalam perkembangan dan pembentukan kompetensi dalam ranah industri kreatif itu sendiri sebagai bagian dari sistem sosial yang lebih luas.

Sebagai bagian dari sistem sosial, pertanyaan sentral yang dikemukakan dalam penelitian ini adalah: sub-sub sistem sosial apa saja yang membangun kreativitas sebagai sebuah ranah? Bagaimana sub-subsistem ini berkaitan atau bersinergi satu sama lainnya, sehingga secara bersama dan melingkupi mendorong bagi tumbuhnya kreativitas dan ide-ide kreatif di sebuah kelompok, kelas atau komunitas? Apakah minimalitas atau maksimalitas elemen-elemen yang membangun sistem kreativitas tersebut ikut menentukan derajad kreativitas dari sebuah sistem atau tidak? Dengan demikian, juga dapat dipertanyakan, apakah kuat atau lemahnya daya kreativitas berbanding lurus dengan kelengkapan elemen-elemen yang membangun sistem dalam ranah kreativitas.

Di samping itu, kreativitas tentu memerlukan berbagai 'sumberdaya' (resources) atau 'modal' (capital), baik yang bersifat individual, material, psikis, sosial, kultural atau simbolik. Sehingga, pertanyaan berikutnya adalah: apakah kepemilikan modalmodal (material, sosial, ekonomi, kultural dan simbolik) menentukan pertumbuhan ide dan produk-produk kreatif pada se- 
buah kelompok, kelas atau komunitas kreatif. Apakah kepemilikan dan kelengkapan modal-modal tersebut berbanding lurus dengan daya kreativitas dan kekayaan ekpresi ide-ide kreatif pada sebuah kelompok, kelas atau komunitas?

Untuk menjawab pertanyaan-pertanyaan di atas, penelitian akan difokuskan di kota Bukittinggi dan sekitarnya, dengan memperhatikan kondisi sosial dan kultural wilayah tersebut, dan melihat perbandingannya dengan kota Bandung dan sekitarnya, untuk mengetahui perbedaan kelengkapan sub-sub sistem kreativitas dan pengaruhnya pada ide-ide kreatif. Sementara, bidang industri kreatif yang akan diteliti difokuskan pada industri makanan kering, dengan melihat berbagai aspek kreativitas yang terlibat di dalamnya, baik dalam desain, kemasan, display, promosi, dan manajemen pemasaran.

\section{METODE}

Penelitian ini menggunakan cara kerja penelitian gabungan, yaitu deduktif dan induktif. Cara kerja penelitian deduktif, adalah penggalian teori-teori yang terkait dengan objek yang dianalisis. Sementara, cara kerja induktif adalah dengan menggali data-data lapangan melalui beberapa informan yang relevan dengan objek yang diteliti. Dalam hal ini, metode etnografi digunakan sebagai metode utama, untuk menggali data-data tentang kondisi geografis, ekonomi, sosial, dan kebudayaan yang mempengaruhi perkembangan kreativitas berbasis lokal. Melalui metode etnografi dapat dilihat sistem kreativitas lokal berdasarkan pandangan masyarakat setempat, untuk menemukan model-model kreativitas yang lebih umum.

Berdasarkan penelitian terdahulu yang bersifat teoritis, telah dikembangkan sebuah model kreativitas sebagai sebuah sistem, yang disebut 'ranah kreativitas' (Piliang, 2011). Model ini menggambarkan kreativitas sebagai sebuah sistem sosial terintegrasi dan melingkupi, dengan subsub sistem yang tidak dapat dipisahkan satu sama lainnya. Kreativitas hanya dapat dihasilkan bila semua sub-sub sistem ini bekerja secara maksimal, dan segala sumberdaya dan modal-modal yang ada diinvestasikan secara maksimal.

Model 'ranah kreativitas' ini dikembangkan, berdasarkan pandangan bahwa kreativitas tidak hanya terkait dengan ranah ekonomi semata sebagaimana yang tampak pada pandangan ahli kreativitas seperti Florida, yang memandang kreativitas sebagai bagian tak terpisahkan dari 'industri kreatif' dan 'ekonomi kreatif', yang tampak terlalu kuat nuansa ekonominya. (Florida, 2003: 68), akan tetapi dengan ranah-ranah lebih luas: sosial, politik, dan kebudayaan.

Dengan menggunakan pendekatan teori Bourdieu tentang 'ranah' dan 'modal', dapat dikemukakan, bahwa kreativitas memiliki dimensi kultural yang lebih melingkupi, ketimbang hanya satu dimensi ekonomi semata, untuk menunjukkan, bahwa berbagai bentuk 'seni komunitas', 'seni rakyat', atau 'festival budaya' yang diproduksi oleh 'komunitas kreatif' tidak berkaitan erat dengan modal ekonomi, tetapi modal sosial, kultural, politik atau bahkan religius. Untuk memahami konsep kreativitas secara lebih komprehensif, kita perlu memperluas konsep 'modal' itu sendiri' dengan mengacu pada konsep sosiologis Bourdieu tentang 'modal' dan 'ranah'. (Bourdieu, 1984: 106).

Konsep 'ranah', berdasarkan teori Bourdieu, menunjukkan sebuah ruang (baik dalam pengertian fisik, sosial, ekonomis, psikologis maupun kultural) yang di dalamnya terjadi 'pertarungan' untuk memperebutkan posisi, khususnya posisi dominan. Posisi-posisi (fisik, sosial, eko- 
nomis, psikologis maupun kultural) di dalamnya ditentukan oleh kepemilikan dan distribusi jenis-jenis sumber daya atau 'modal' yang berbeda-beda. Semakin kuat atau besar modal yang dimiliki, semakin berpeluang untuk mendapatkan posisi yang lebih tinggi dalam ranah sosial. Struktur 'ranah'sangat menentukan strategi atau taktik-taktik yang harus digunakan dalam pertarungan, khususnya dalam menginvestasikan dan mendistribusikan modal yang dimiliki, untuk mendapatkan keuntungan tertentu, sebagai cara memenangkan pertarungan (Bourdieu, 1993: 30).

Dengan menggunakan cara kerja kebudayaan di atas, dapat dikemukakan, bahwa karya-karya kreatif termasuk karya kreatif dalam desain kuliner, juga berkembang dan dapat dipahami melalui sebuah 'pertarungan gagasan' di dalam sebuah ranah khusus, yang disebut 'ranah kreativitas'. Sebagaimana ranah pada umumnya, di dalam ranah kreativitas berlangsung pertarungan untuk memperebutkan posisi dominan dalam hal ide atau gagasan kreatif, yang keberhasilannya sangat ditentukan oleh kepemilikan modal serta efek penguasaan posisi tertentu di dalam struktur ranah" (Bourdieu, 1993: 30).

Dengan demikian, 'modal' memiliki peran sangat sentral dalam setiap ranah pertarungan, termasuk pertarungan gagasan kreatif. 'Modal', dalam hal ini, dipahami dalam pengertiannya yang sangat luas, yang melingkupi "modal ekonomi' (economic), yaitu semua objek material yang mempunyai nilai ekonomi (uang, emas, tanah, bangunan); 'modal simbolik' (symbolic capital') yang meliputi seluruh yang nonmaterial tetapi memiliki nilai kultural tertentu (prestise, status, otoritas); 'modal budaya' (cultural capital), yang meliputi ragam barang atau sistem-sistem yang luas yang memberi raut pada bentuk dan maknamakna budaya (bahasa, pendidikan, seni);
(Harker, 1990: 13) dan 'modal sosial' (social capital) 'struktur relasi' di antara kelas atau kelompok-kelompok di dalam sebuah masyarakat, serta semua hak milik terkait yang memberi kekuatan dan nilai tertentu pada masing-masing serta efek yang dihasilkannya terhadap praktik (Bordieu,1984: 106).

Berdasarkan pandangan Bourdieu tentang 'ranah' dan 'modal', di sini dapat diusulkan sebuah 'ranah' khusus kreativitas, yang disebut sebagai 'ranah kreativitas' (field of creativity). 'Ranah kreativitas' dapat didefinisikan sebagai "sebuah ruang pertarungan kreativitas terstruktur untuk menghasilkan perbedaan dan keberbedaan yang ditentukan oleh distribusi jenis-jenis 'modal kreatif' berbeda yang diinvestasikan di dalamnya, serta bagaimana semuanya menentukan derajad kreativitas dan ide-ide kreatif yang dihasilkan di dalamnya.

Dalam hal ini, dapat diidentifikasikan empat ranah yang mengkonstruksi sebuah lingkungan kreatif: 'ranah ekspresi' (field of expression) sebagai sebuah ranah yang di dalamnya ide-ide baru atau inovasi dihasilkan; 'ranah produksi' (field of production) se-

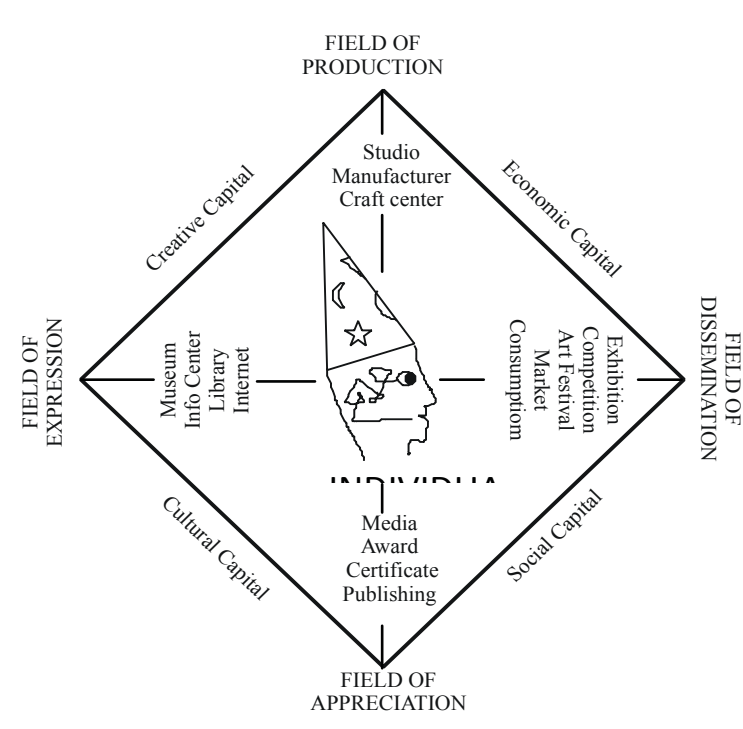

Gambar 1:

Medan kreativitas dan lingkungan manusia kreatif yang mendukung bagi produksi ide-ide baru atau inovasi 
bagai sebuah ranah yang di dalamnya ideide baru direalisasikan melalui berbagai 'cara produksi' (yang tidak hanya 'produksi ekonomi', tetapi juga 'produksi sosial', 'produksi kultural', bahkan 'produksi keagamaan'); 'ranah diseminasi' (field of dissemination) sebagai sebuah ranah yang di dalamnya 'produk-produk kreatif' didiseminasikan dan didistribusikan; dan 'ranah apresiasi' (field of appreciation) sebagai sebuah ranah 'wacana' (discourse), yang di dalamnya karya-karya kreatif diapresiasi dan diberikan nilai melalui standard penilaian dan nilai tertentu (Piliang, 2011).

Model 'ranah kreativitas' di atas, dapat digunakan untuk menganalisis 'derajad kreativitas' sebuah kelompok, kelas atau komunitas kreatif tertentu, sebagaimana yang dikatakan oleh Florida (2003: 68). Asumsinya adalah, bahwa kreativitas, sebagaimana dikatakan oleh Csikszentmihalyi, tidak sekadar menjelaskan individu yang mengekspresikan pemikiran tak biasa, baru, orisinil, segar, dan mencerahkan, tetapi menjelaskan juga bahwa semuanya hanya dapat berlangsung sebagai bagian dari sistem sosial dan kultural. Artinya, kreativitas tidak bersifat individual melainkan sosial dan kultural, yang melibatkan sebuah sistem budaya yang lebih luas.

Oleh karena kreativitas adalah 'produk sosial', yang diproduksi di dalam sebuah 'ruang sosial' atau 'medan sosial', kreativitas harus dipahami sebagai sebuah proses komprehensif yang melibatkan semua ranah terkait (ranah ekspresi, produksi produksi, ranah diseminasi dan ranah apresiasi) sebagai sebuah 'ranah total' yang disebut ranah kreativitas, dan yang secara sinergis mema$\mathrm{cu}$ dorongan kreatif dan karya-karya kreatif. Model ranah kreativitas ini dapat digunakan untuk memahami derajad kreativitas pada berbagai sistem kreativitas yang ada dalam masyarakat, termasuk kreativitas dalam desain kuliner.

\section{HASIL DAN PEMBAHASAN}

Ranah kreativitas di dalam sebuah masyarakat sangat ditentukan oleh berbagai faktor, baik faktor geografis, ekonomi, sosial, politik dan kultural. Berbagai faktor tersebut akan menentukan apakah di dalam ranah kreativitas segala sumberdaya pikiran, keahlian, pengetahuan dan material yang ada (yang secara umum disebut 'modal') dapat digerakkan secara maksimal, sehingga menghasilkan ide-ide kreatif, dan yang mampu direalisasikan menjadi produk kreatif sebagai bagian dari pengembangan ekonomi kreatif.

Di dalam penelitian ini, model 'ranah kreativitas' diujikan pada sebuah ruang sosial khusus sebagai kasus studi, yaitu pada industri makanan di daerah Bukittinggi dan sekitarnya dan dibandingkan dengan daerah Bandung dan sekitarnya. Di daerah Bukittinggi dan sekitarnya, kreativitas sangat ditentukan oleh berbagai faktor. Pertama, faktor geografis, yaitu posisi geografis Bukittinggi sebagai kota pariwisata, perdagangan, industri dan transit yang strategis, yang memungkinkan tumbuhnya industri kreatif. Kedua, faktor ekonomi, yaitu ada upaya berkelanjutan dari pemerintah daerah untuk mengembangkan Industri rakyat berbasis potensi daerah, serta berkembangnya Bukittinggi dan sekitarnya sebagai tujuan pariwisata mancanegara, yang membuka peluang pengembangan industri. Ketiga, faktor budaya, yaitu faktor sistem budaya yang hidup di dalam masyarakat, yang mempengaruhi cara pikir, pandangan hidup dan etos kerja.

Di antara faktor kultural yang mempengaruhi tumbuhnya kreativitas dan terbangunnya sistem inovasi di daerah Bukittinggi dan sekitarnya dapat dijelaskan sebagai berikut. Pertama, nilai kultural menyangkut makanan, yaitu hidupnya dua atau lebih nilai secara bersamaan: kebaruan dan keaslian, nostalgia dan eksploratif, etnisitas 
dan kosmopolitan. Kedua, pandangan hidup (world view) dari masyarakat, terutama pandangan tentang ekonomi. Terdapat berbagai pandangan ekonomi yang berbeda di daerah ini berdasarkan sifatnya, yaitu: 1) spiritual, bahwa ekonomi adalah bagian dari ibadah dan amanah, sehingga berusaha dilakukan sebatas yang digariskan syariat; 2) ekspansif, bahwa prinsip-prinsip modern persaingan, perluasan, pengembangan (franchaice, multinasional, venture), ekspansi dan jiwa kosmopolitanisme; dan 3) keseimbangan, bahwa usaha adalah bagian dari aktivitas yang harus mengikuti hukum alam, sambil menekankan keseimbangan dengan lingkungan dan masyarakat, serta mengutamakan kebersamaan (awak samo awak) ketimbang kompetisi kapitalistik.

Berdasarkan penelitian lapangan, dapat dijelaskan berbagai kondisi 'ranah kreativitas', yang dibedakan berdasarkan kelengkapan subsistemnya. Dengan mempertimbangkan empat ranah kreativitas tersebut di atas, dapat diidentifikasi tiga model sistem inovasi yang berkembang secara simultan di lingkungan industri makanan di dua daerah berbeda: daerah Bukittinggi dan sekitarnya dan Bandung dan sekitarnya. 'Sistem inovasi' dipahami di sini sebagai kesatuan terintegrasi elemen-elemen yang membangun se- buah ranah kreativitas, susunan, tatanan dan interelasi di antara semuanya, untuk memproduksi ide kreatif dan produk inovatif.

Pertama, sistem inovasi terbuka (open system), yaitu sistem inovasi yang bersifat dinamis, kosmopolit, komprehensif dan membuka diri terhadap berbagai bentuk perubahan fundamental atau radikal. Sistem terbuka ini ditunjukkan oleh ranah kreativitas di kota Bandung dan sekitarnya, yang memiliki sub-ranah ekspresi, produksi, diseminasi, dan apresiasi yang relatif lengkap. Kedua, sistem inovasi liminal (liminal system), yaitu sistem inovasi yang mulai memperkenalkan perubahan, tetapi masih terikat pada nilai-nilai tradisi dan kultural yang ada. Ketiga, sistem inovasi tertutup (closed system), yaitu sistem yang sangat kuat terikat pada nilai-nilai kebiasaan, tradisi, habitus, konservasi, sehingga hanya memberi toleransi perubahan minor atau parsial, bukan perubahan fundamental.

Kedua model terakhir ini ditunjukkan oleh ranah kreativitas di kota Bukittinggi dan sekitarnya, di mana subsistem dalam ranah kreativitasnya tidak lengkap, bahkan sangat minimal, yaitu hanya memiliki ranah produksi saja, tetapi tidak ada individu kreatif, diseminasi (pameran, festival) dan apresiasi (kritikus).

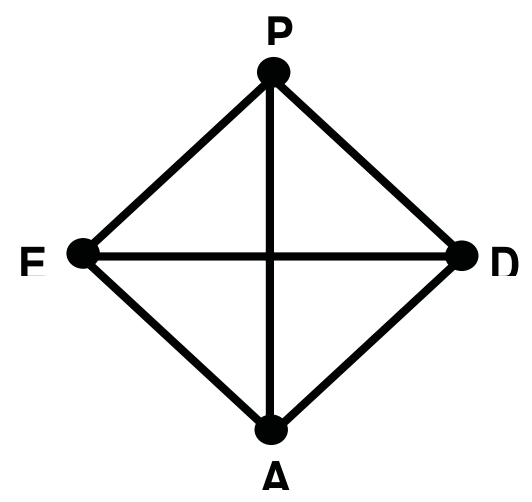

Open System

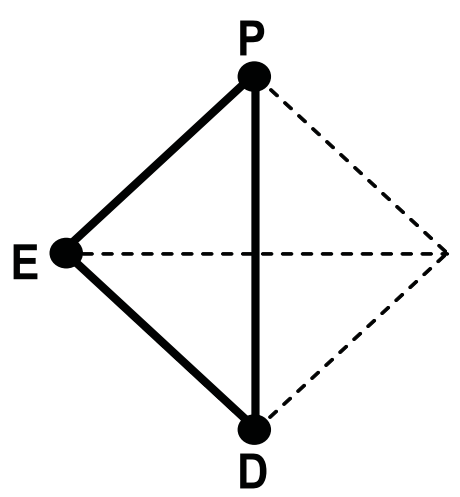

Liminal System

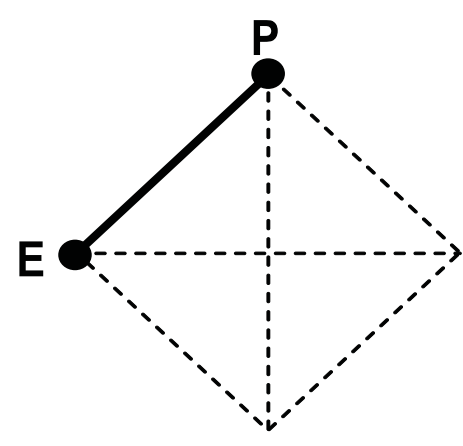

Close System

Gambar 2

Skema tiga sistem dalam ranah kreativitas 
Beberapa ciri umum ketiga sistem inovasi dalam ranah kreativitas di atas dapat dijelaskan. Pertama, sistem terbuka cenderung tumbuh, dinamis, inspiratif, menggerakkan, terbuka, lengkap, ekspansif dinamis, partisipatif, dan proaktif. Kedua, sistem liminal cenderung bersifat ekspansif linier, non-partisipatif, kurang lengkap, "me-too", reaktif. Ketiga, sistem tertutup cenderung bersifat statis, stagnan, repetitif/ reproduktif, tertutup, tidak lengkap, pasif, non-partisipatif.

Meskipun demikian, ketiga sistem dalam ranah kreativitas di atas semuanya memiliki muatan kreativitas, hanya saja berbeda-beda intensitas dan kedalamannya. Pada sistem tertutup medan kreativitas itu lebih terbatas dibandingkan sistem terbuka, yang membuka peluang bagi perubahan radikal. Semua sistem tersebut memiliki aspek positif dan negatifnya masing-masing.

Berdasarkan ciri-ciri sistem inovasi di atas, dapat dijelaskan lebih lanjut manifestasi sistem-sistem tersebut pada masingmasing daerah penelitian.

Pertama, sistem terbuka. Di dalam sistem terbuka, ada upaya sistematis untuk menggunakan, mencari dan mengembangkan pengetahuan (knowledge system). Sistem ini memiliki aksesibilitas dan jejaring pengetahuan, misalnya penggunaan media elektronik dan cetak, sehingga membuka lebih luas ketersediaan informasi. Selain itu, dalam sistem terbuka, aspek pengalaman dalam membentuk pengetahuan dan gagasan juga berperan penting, didukung jiwa kosmopolitan yang ditunjukkan oleh sikap terbuka, dinamis dan mencari daerah atau pengalaman baru. Dengan demikian, ekonomi yang dikembangkan dalam sistem terbuka ini adalah ekonomi berbasis pengetahuan, juga berbasis jaringan dan bermuatan lokal. Sekalipun pengetahuan yang dikembangkannya adalah pengetahuan bermuatan lokal (indigenous know- ledge), namun semangat bereksperimentasi dan mengembangkan ide-ide baru yang kreatif sangat menonjol. Sistem ini paling menonjol terlihat pada Usaha Kecil Menengah (UKM) Kiniko.

Di Kiniko yang berlokasi di sebuah desa di Batusangkar, meskipun sistem produksinya masih menggunakan bahan baku, keahlian atau keterampilan lokal, serta peralatan turun temurun, namun dijalankan dengan menggunakan cara-cara industri modern, metode pengujian ilmiah melalui standard Badan Pengawasan Obat-obatan dan Makanan (BPOM). Selain itu, Kiniko melakukan pemberdayaan masyarakat marjinal, khususnya pemberdayaan perempuan (seperti para janda), dan pemberdayaan industri rumahan. Kiniko pun merintis kerja sama dengan sekolah-sekolah (seperti Sekolah Tata Boga) dalam memproduksi jenis produk makanan baru.

Dalam hal sistem diseminasi, Kiniko aktif mengikuti berbagai pameran lokal, nasional dan internasional. Selanjutnya, agar bisa lebih menjaring turis domestik dan manca negara, Kiniko menjalin kerjasama dengan agen perjalanan wisata untuk membawa para turis tersebut menjadi konsumen. Kiniko pun melakukan promosi melalui internet dan media-media lainnya. Untuk memudahkan pembawaan barang oleh konsumen, Kiniko menyediakan layanan pengiriman paket makanan. Sementara untuk penjualan, diadakan berbagai event khusus untuk menarik pembeli, seperti mengadakan gelanggang silat dan pertunjukkan seni tradisional.

Untuk sistem apresiasi, Kiniko mendapat penghargaan dan pengakuan dari masyarakat akan perusahaan dan produknya. Selain itu, ia juga mendapatkan pengakuan dari pemerintah daerah dan peliputan oleh media (cetak maupun elektronik). Sistem inovasi yang dikembangkan Kiniko memiliki unsur-unsur yang lengkap, dan didukung oleh modal-modal yang kuat: modal 
budaya (pendidikan, pengalaman, pengetahuan dari sang pemilik), modal sosial (jaringan luas, baik secara sosial maupun virtual), modal simbolik (pengaruh dalam masyarakat yang kuat serta status sosial yang tinggi)

Kedua, sistem liminal. Dalam sistem liminal ini, sistem ekspresi yang muncul kurang didukung inisiatif dan lebih bersifat reaktif, seperti pada Hj. Ramadani (Sanjay Mintuo), Bika Talago, dan Martabak Kaka di kota Bukittinggi. Mereka lebih cenderung menunggu permintaan atau keinginan konsumen. Sementara untuk sistem produksi, masih mempertahankan cara masak tradisional, sekaligus mempertontonkan kepada konsumen (untuk hiburan), disertai modifikasi alat dan teknik memasaknya. Untuk produksi masih dalam skala terbatas, karena ada upaya mempertahankan kualitas. Di samping itu, pertimbangan intensitas pengunjung yang datang disesuaikan dengan kemampuan produksi atau customize production, yaitu custom dalam jumlah, bukan pada bentuk makanannya, sehingga tidak dikenal produksi massal.

Untuk sistem diseminasi, masih menggunakan pemasaran dari mulut ke mulut, dan bukannya menggunakan sarana media promosi agar menjangkau konsumen yang lebih luas. Hal ini salah satunya disebabkan oleh posisi tempat berjualan dan produksi yang ada sangat strategis sehingga memungkinkan banyak orang tahu dengan sendirinya karena menjadi perlintasan banyak turis asing mau pun domestik. Kondisi memupuk perasaan cukup sehingga tidak memiliki kepentingan untuk melakukan diseminasi melalui kegiatan pameran atau sejenisnya (seperti sistem pemasaran modern). Adapun untuk sistem apresiasi, mereka umumnya tidak memanfaatkan atau membangun dan tidak memanfaatkan testimoni dari pengunjung atau pihak lain (seperti media, pemerintah, connosieur).

Ketiga, sistem tertutup. Dalam sistem tertutup, sistem ekspresinya berupa pengetahuan turun-temurun, hanya mengandalkan hal yang sudah ada atau diperoleh, serta meneruskan tradisi masa lalu. Dalam sistem ini, pengetahuannya hanya bersifat mengkonservasi atau memelihara bentuk, rasa, selera yang ada. Perubahan bentuk, rasa dan bahan sangat terbatas, hanya berupa variasi dari yang sudah ada, dan berorientasi ke warisan rasa dan bentuk masa lalu. Sementara, untuk sistem produksi, umumnya dilakukan dengan sistem beli putus dan assembling, yaitu produser makanan setengah jadi menyediakan

\begin{tabular}{|l|l|l|l|}
\hline $\begin{array}{l}\text { KOMPARASI SISTEM } \\
\text { KREATIVITAS }\end{array}$ & \multicolumn{1}{|c|}{ TIPOLOGI } & \multicolumn{1}{c|}{ ASPEK POSITIF } & \multicolumn{1}{c|}{ ASPEK NEGATIF } \\
\hline Open system & $\begin{array}{l}\text { tumbuh, dinamis, inspi- } \\
\text { ratif, liberal, mengge- } \\
\text { rakkan, terbuka, leng } \\
\text { kap, ekspansif dinamis, } \\
\text { partisipatif, proaktif, } \\
\text { pragmatis. }\end{array}$ & $\begin{array}{l}\text { skala besar, tumbuh cepat, } \\
\text { menyerap labor, pertumbuh- } \\
\text { an cepat, fase inovasi cepat } \\
\text { dan dinamis, insustainable, } \\
\text { asosial, produktif. }\end{array}$ & $\begin{array}{l}\text { beresiko, rapuh, vulner } \\
\text { able, kontrol sistem le- } \\
\text { mah. }\end{array}$ \\
\hline Liminal system & $\begin{array}{l}\text { ekspansif linier, non-par- } \\
\text { tisipatif, kurang leng- } \\
\text { kap, "me-too", reaktif, } \\
\text { konservatif. }\end{array}$ & $\begin{array}{l}\text { pertumbuhan terkendali, } \\
\text { menjaga nilai, menjaga ke- } \\
\text { seimbangan, ramah lingkung- } \\
\text { gan, konservasi adat. }\end{array}$ & $\begin{array}{l}\text { tidak fokus, ambigu, } \\
\text { tidak cukup sustain, } \\
\text { kurang proaktif, ambi- } \\
\text { valen sistem, mediocre. }\end{array}$ \\
\hline Closed system & $\begin{array}{l}\text { statis, stagnan, repeti- } \\
\text { tif/reproduktif, tertu- } \\
\text { tup, tidak lengkap, pa } \\
\text { sif, non-partisipatif, } \\
\text { konservatif. }\end{array}$ & $\begin{array}{l}\text { stabil, kuat, recovery cepat, } \\
\text { kontrol lebih mudah, sustain } \\
\text { able, tanggungjawab sosial, ko } \\
\text { hesi sosial yang kuat, proteksi } \\
\text { tinggi, konservasi adat. }\end{array}$ & $\begin{array}{l}\text { pertumbuhan lambat, } \\
\text { lebih monoton, fase } \\
\text { inovasi lambat, inovasi } \\
\text { terbatas. }\end{array}$ \\
\hline
\end{tabular}

Tabel 1

Komparasi tiga sistem kreativitas 
bahan dasar setengah jadi, kemudian pemberian rasa dan pewarnaan dilakukan oleh distributor dan penjual. Begitu pula dengan pengemasannya. Sistem produksi masih bersifat sentra, yaitu produksi berbasis sentra produksi rakyat.

\section{PENUTUP}

Sistem inovasi di dalam sebuah kelompok atau kelas sosial sangat ditentukan oleh tipologi ranah kreativitasnya, kepemilikan dan investasi modal-modal khusus (yaitu modal ekonomi, kultural, simbolik dan sosial) serta kelengkapan sub-sub ranah yang membangun ranah kreativitas. Semakin besar modal yang diinvestasikan dan semakin lengkap sub-sub sistem dalam ranah kreativitas, semakin besar kemungkinan dihasilkannya ide-ide kreatif dan produkproduk inovatif di dalamnya. Sebaliknya, semakin minim modal dan tak lengkap sub-sistem dalam ranah kreativitas, semakin kecil peluang menghasilkan gagasan kreatif dan produk-produk inovatif.

Memang, dapat juga disimpulkan, bahwa sistem yang terlalu terbuka akan membuka potensi bagi resiko yang tinggi (high risk), yaitu resiko karena kurang adanya kontrol dari berbagai aspek (besaran, sistem, regulasi, moneter), sehingga kreativitas berkembang tanpa dilandasi oleh sebuah skenario besar yang ingin dicapai, misalnya melindungi budaya lokal. Resiko ini, misalnya tampak pada industri kreatif di kota Bandung dan sekitarnya. Sebaliknya, sistem yang terlalu tertutup juga memiliki resiko yang disebabkan pengendalian dan proteksi yang terlalu ketat dan kuat misalnya terhadap nilai-nilai lokal, selera setempat, kebiasaan, tradisi dan tabu, sehingga peluang bagi tumbuhnya ide-ide kreatif tertutup. Sistem ekonomi kreatif tentu akan lebih berkembang atau bekerja dalam sistem yang terbuka. Industri kreatif akan tumbuh ketika sebuah kota memiliki kelengkapan modal dan ranah-ranahnya.

Selain itu, sebagai sebuah sistem, dapat disimpulkan juga bahwa perkembangan sistem inovasi di dalam sebuah kelompok atau kelas sosial pada umumnya bekerja secara gradual, yaitu pergeseran dari 'sistem tertutup', ke arah 'sistem liminal' dan akhirnya 'sistem terbuka'. Pergeseran ini hanya dapat berlangsung bila ada 'agen-agen' tertentu yang berinisiatif untuk memulai ide kreatif, dan di pihak lain, ada inisiatif dari berbagai pihak terkait, untuk membangun ranah produksi, ranah diseminasi dan ranah apresiasi yang lebih terbuka dan terintegrasi. Bila semua ini tidak ada, maka peluang untuk mengembangkan dan merealisasikan ide kreatif dan produk inovatif semakin tertutup.

\section{Daftar Pustaka}

Bourdieu, Pierre

1984 A Social Critique of the Judgement of Taste. US: Harvard University Press

1991 Language and Symbolic Power. Cambridge: Polity Press

1993 The Field of Cultural Production. Cambridge: Polity Press

Csikszentmihalyi, Mihaly

1990 Flow: The Psychology of Optimal Experience. New York: Harper Perennial

1993 The Evolving Self: A Psychology for the Third Millenium. San Fransisco: Harper Perennial

1997 Creativity: Flow and the Psychology of 
Discovery and Invention. New York: Harper Perennial

Florida, Richard

2003 The Rise of the Creative Class. Melbourne: Pluto Press

Harker, Richard (ed)

1990 An Introduction to the Work of Pierre Bourdieu. MacMillan
Howkins, John

2001 The Creative Economy: How People Make Money From Ideas. Penguin Books

\section{Yasraf Amir Piliang}

2011 "Creativity as the Conceptual and Pragmatic Framing of Mind", International Journal Melintas, Vol 27, No 2 